\title{
Endophytic mycobiota associated to plants of Vaccinium corymbosum L. in Cañete valley- Perú
}

\author{
Micobiota endófita asociada a plantas de Vaccinium corymbosum L. en el valle Cañete- Perú \\ Micobiota endofítica associada a plantas de Vaccinium corymbosum L. no vale do Cañete - Perú
}

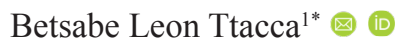

Almendra Astete Farfán ${ }^{2}$ :잉 (10)

Luz Leonor Mattos Calderón ${ }^{3}$ (a) (1)

Enrique Arévalo Gardini ${ }^{4}$ : 20

Rev. Fac. Agron. (LUZ). 2022, 39(1): e223922

ISSN 2477-9407

DOI: https://doi.org/10.47280/RevFacAgron(LUZ).v39.n1.22

\section{Crop Production}

Associate editor: Professor Beltran Briceño
${ }^{1}$ Escuela profesional de Agronomía, Facultad de Ciencias Agrarias, Universidad Nacional de Cañete. Jr. San Agustín 124, San Vicente de Cañete Lima, Perú.

${ }^{2}$ Laboratorio de Sanidad Vegetal, Facultad de Ciencias Agrarias, Universidad Nacional de Cañete. Jr. San Agustín 124, San Vicente de Cañete Lima, Perú.

${ }^{3}$ Escuela Profesional de Agronomía, Departamento Académico de Fitopatología, Universidad Nacional Agraria La Molina, Apartado postal 12-056 - La Molina / Lima-Perú.

${ }^{4}$ Universidad Nacional Autónoma del Alto Amazonas, Yurimaguas, Loreto, Perú. Instituto de Cultivos Tropicales, Taparopo, San Martín, Perú.

Received: 12-05-2021

Accepted: 01-12-2021

Published: 04-03-2022

\section{Keywords:}

Fungus

Blueberry

Colonization

Identification

Strains

\begin{abstract}
Endophytic fungi (EF) are microorganisms that live asymptomatically within plant tissues. They can confer benefits to the plant as inducers of resistance to pests and diseases, tolerance to abiotic factors, plant growth promoters and mycoparasites of pathogens. This study aimed to isolate, identify, and determine occurrence frequency of endophytic fungi in stems and leaves of blueberry plants collected from ten farms in Lima and Ica Region, Peru. Productive branches of 39 healthy plants were sampled. For the isolation of EF, 702 tissue sections were disinfected and transferred to Petri dishes with potato dextrose agar (PDA) medium, and reproductive structures were induced for identification. A total of $134 \mathrm{EF}$ strains were isolated successfully. Nine genera were identified (Trichoderma, Aspergillus, Alternaria, Ulocladium, Cladosporium, Fusarium, Nigrospora, Lasiodiplodia and Stemphylium). EF occurrence frequency varied greatly between organs, being in leaves more frequent than the stems; likewise, the genera Alternaria and Cladosporium were the most frequent and with most colonized in plant tissues, while Aspergillus, Ulocladium and Lasiodiplodia were the least frequent. These strains could be useful to control plant diseases and, therefore, of great interest in sustainable agriculture.
\end{abstract}




\section{2-7| Rev. Fac. Agron. (LUZ). 2022, 39(1): e223922. January - March. ISSN 2477-9407.}

\section{Resumen}

Los hongos endófitos (HE) son microorganismos que viven de manera asintomática dentro de los tejidos vegetales. Pueden conferir beneficios a la planta, comoinductores de resistencia a plagas y enfermedades, tolerancia a factores abióticos, promotores de crecimiento vegetal y micoparásitos de patógenos. El objetivo del presente trabajo fue aislar e identificar los hongos endófitos,para determinar su frecuencia de aparición en tallos y hojas de plantas de arándano,colectadas en 10 fundosde la región Lima e Ica, Perú. Se muestrearon ramas productivas de 39 plantas sanas, y fueron llevadas al laboratorio de Sanidad Vegetal de la Universidad Nacional de Cañete. Para el aislamiento de HE, 702 secciones de tejidos fueron desinfestados y transferidos a placas Petri con medio de cultivo papa dextrosa agar (PDA) y se indujo estructuras de reproducción para la identificación. Un total de 134 cepas de HE fueron aisladas, de los cuales se identificaron nueve géneros (Trichoderma, Aspergillus, Alternaria, Ulocladium, Cladosporium, Fusarium, Nigrospora, Lasiodiplodiay Stemphylium). La frecuencia de aparición de los HE fue muy variada según los órganos. Las hojas tuvieron mayor frecuencia que los tallos; así mismo, los géneros Alternaria y Cladosporium resultaron ser los más frecuentes y con mayor colonización en los tejidos de las plantas mientras que Aspergillus, Ulocladium y Lasiodiplodia fueron los menos frecuentes. Estas cepas podrían ser útiles para el control de enfermedades vegetales $\mathrm{y}$, por consiguiente, de gran interés en la agricultura sostenible.

Palabras clave: Hongo, arándano, colonización, identificación, cepas.

\section{Resumo}

Os fungos endofíticos (FE) são microrganismos que vivem de forma assintomática nos tecidos vegetais. Eles podem conferir benefícios à planta, como indutores de resistência a pragas e doenças, tolerância a fatores abióticos, promotores de crescimento vegetal e micoparasitas de patógenos. O objetivo deste trabalho foi isolar e identificar fungos endofíticos, para determinar sua frequência de aparecimento em caules e folhas de plantas de mirtilo, coletados em 10 fazendas na região de Lima e Ica, Peru. Ramos produtivos de 39 plantas sadias foram amostrados e levados ao laboratório de Fitossanidade da Universidade Nacional de Cañete. Para o isolamento de FE, 702 cortes de tecido vegetal foram desinfetados e transferidos para placas de Petri contendo como meio de cultura batata dextrose ágar (PDA), e as estruturas de reprodução foram induzidas para identificação. Um total de 134 cepas de FE foram isoladas, das quais nove gêneros foram identificados (Trichoderma, Aspergillus, Alternaria, Ulocladium, Cladosporium, Fusarium, Nigrospora, Lasiodiplodia e Stemphylium). A frequência de aparecimento de FE foi muito variada de acordo com os órgãos. As folhas tiveram maior frequência do que os caules; da mesma forma, os gêneros Alternaria e Cladosporium foram os mais frequentes e com maior colonização nos tecidos vegetais, enquanto Aspergillus, Ulocladium e Lasiodiplodia, foram os menos frequentes. Essas cepas podem ser úteis para o controle de doenças de plantas e,portanto, de grande interesse uma agricultura sustentável.

Palavras-chave: Fungo, mirtilo, colonização, cepas, identificados.

\section{Introduction}

The blueberry is the second most exported product of the Peruvian fruit and vegetable basket. The United States of America is one of the main destinations for Peruvian exports with a 55\% share during the 2019-2020 agricultural campaign, because they are the largest consumer of this fruit worldwide (Redagricola, 2020). The requirements of the global blueberry market require organic production of this fruit, with the biological control of diseases being one of the key factors in this practice. A study of its endophytic mycobiota would allow the identification of microorganisms that could help in this process, contributing to the current demands of international markets.

Endophytic fungi are symbiotic organisms that live in association with plants for most or all of their life cycle. These microorganisms cover different orders, they are found inside the tissues, in the intercellular spaces and sometimes, intracellularly in leaves, stems and flowers, absorbing nutrients from the plant without producing symptoms of any disease, on the contrary they provide protection against biotic agents and abiotic (Busby et al., 2016; Carroll, 1988; Lugtenberg et al., 2016; Mane et al., 2018). In the process of biocontrol of diseases, these microorganisms protect the host plant mainly through antibiosis, parasitism and competition mechanisms, which by inhibiting the growth of plant pathogens, result in better plant performance (Segaran and Sathiavelu, 2019).

Currently, endophytic fungi are investigated in many crops, due to their importance in plants (Busby et al., 2016; Mane et al., 2018). They are found in some species of Vaccinium and are divided into endophytic, pathogenic and ectotrophic (Miao et al., 2013). In leaves of Vaccinium dunalianum, the existence of a high diversity of these fungi is reported, managing to identify taxa with potential antimicrobial activity, being a source of natural bioactive compounds for future agroindustrial applications (Fan et al., 2020; Li et al., 2016). However, in Vaccinium corymbosum there are no studies on the presence of these microorganisms. The report of associated endophytic fungi in blueberry production will be very useful for the search for strains with potential for biocontrol of diseases in this crop. With the isolation of endophytic fungi from plants, biologically active agents can be produced on a large commercial scale, without affecting ecological biodiversity, since they are easily cultivated in the laboratory (Mane et al., 2018). For these reasons, the objective of this research is to isolate, identify and determine the frequency of appearance of endophytic fungi in stems and leaves of blueberries (Vaccinium corymbosum L.) produced in the Cañete valley in Lima, Peru.

\section{Materials and methods}

\section{Sample Collection}

During the months of January, February and March 2020, 39 healthy blueberry plants of the Biloxi variety, three years old, were sampled in 13 production lots belonging to ten farms in four districts of the province of Cañete, Lima Region (Nuevo Imperial, Imperial, Roma and Quilmaná) and on a farm in the district and province of Pisco, Ica Region under a definitive soil production system (Table 1). The climate of the province of Cañete is temperate with an average temperature of $13{ }^{\circ} \mathrm{C}$ in winter and $28^{\circ} \mathrm{C}$ in summer and an average annual rainfall of $11.4 \mathrm{~mm}$. The crop production system is carried out in black polyethylene bags (instead of pots) containing a substrate composed of peat and rice husks, all plantations are 
irrigated and fertilized through the system called "drip irrigation". A non-probabilistic - intentional or convenience sampling method was used (Arias-Gómez et al., 2016), three blueberry plants with the best characteristics in terms of growth and health were selected from each production lot. For each plant, productive branches were extracted from the lower, middle and upper third, the samples were labeled, deposited in polypropylene bags and taken to the Plant Health Laboratory of the Universidad Nacional de Cañete (UNDC) being kept at $4{ }^{\circ} \mathrm{C}$ for 24 to 48 hours until processing.

\section{Isolation of endophytic fungi}

To obtain plant tissue sections, three leaves and three stem pieces were taken from each third of the blueberry plant; For each leaf, a section of $1 \mathrm{~cm}^{2}$ was obtained between the central rib and the edge of the leaf, and $1 \mathrm{~cm}$ lenth for each piece of stem, having 18 sections per plant and 54 sections per lot (three plants). For the isolation of endophytic fungi, the superficial disinfestation of the sections of stems and leaves was carried out inside a biosafety cabinet, by means of immersion; previously, the different sections were washed with sterile distilled water (ADE), followed by $3 \mathrm{~min}$ in $2 \%$ sodium hypochlorite, $1 \mathrm{~min}$ in $70 \%(\mathrm{v} / \mathrm{v})$ alcohol, and three washes with ADE (De Sousa Leite et al., 2013). Sterilized tissue sections were placed on sterile paper towels to dry. The material was then cut into small fragments (approximately $5 \mathrm{~mm}^{2}$ ), and a total of 702 tissue sections (from 39 plants) were aseptically transferred to Petri dishes (6 sections per plate) containing potato dextrose agar (PDA) culture medium with chloramphenicol (500 mg. $\left.\mathrm{L}^{-1}\right)$ to rule out the presence of bacteria (Lima and Cavalcanti, 2014; Mane et al., 2018). The seeded Petri dishes were incubated in the dark at $25{ }^{\circ} \mathrm{C}$ for seven days, after this time, the strains were purified by successive picking of the youngest fungal mycelial edges until an axenic culture was obtained, then they were placed under artificial light for seven days to induce the production of sexual and asexual reproductive structures for identification. Strains that failed to form reproductive structures were left under light for up to 30 days and were observed daily for structures. The presence of a fungus was recorded as positive if it was detected in an organ segment. The colonization percentage was determined for each plant as the total number of sections colonized by the fungus in relation to the total number of fragments per 100 (Russo et al., 2016).

\section{Morphological identification of endophytic fungi}

The identification of the strains of endophytic fungi was carried out at the genus level, using the conventional method based on their morphological characteristics (Aharwal and Kumar, 2016). From the axenic cultures of the fungi in PDA, the cultural characteristics of the colony were observed, such as appearance, diameter, texture and coloration, and the microscopic characteristics: type and size of the vegetative and reproductive structures. Fragments of mycelia were extracted from the cultures and placed on slides containing lactophenol, the structures were visualized with an Olympus brand binocular optical microscope, model CX23, series 7L88230 and with the use of taxonomic keys of Barnett and Hunter (1998), Barron (1968) and Watanabe (2002) endophytic fungal strains were identified to the genus level.

\section{Analysis of data}

To analyze the relationship between the variables presence or absence of each of the genera of endophytic fungi detected by organs (leaves and stems) and production lots, the non-parametric Pearson Chi-square test was used with the statistical program Infostatversión 2008 (Di Rienzo et al., 2008).

\section{Results and discussion}

\section{Isolation and identification of endophytic fungi from leaves and stems}

In this study, a total of 133 strains of endophytic fungi were isolated from healthy plant tissues of Vaccinium corymbosum L., 82 strains from leaves and 51 from stems. According to the cultural and morphological characteristics of the fungi, nine genera belonging to the Ascomycota division were identified: Alternaria, Aspergillus, Cladosporium, Fusarium, Lasiodiplodia, Nigrospora, Stemphylium, Trichoderma and Ulocladium (figure 1); There was also a group of endophytic fungi (21 strains) that did not form reproductive structures, which is why they were called sterile mycelium.

\section{Table 1. Sampling locations for blueberry plants in the province of Cañete and Pisco, 2020, Peru.}

\begin{tabular}{|c|c|c|c|c|c|c|c|}
\hline Zone & Lot & Province & District & Farm & South Latitude & West Longitude & $\begin{array}{l}\text { Altitude } \\
\text { (m a.s.l) }\end{array}$ \\
\hline Zone 1 & Lot 1 y 2 & Cañete & Quilmaná & Blueagro & $12^{\circ} 57^{\prime} 17^{\prime \prime}$ & $76^{\circ} 21^{\prime} 39^{\prime \prime}$ & 169 \\
\hline Zone 2 & Lot 3 & Cañete & Quevo Imperial & Agropec & $13^{\circ} 00^{\prime} 35^{\prime \prime}$ & $76^{\circ} 21^{\prime} 09^{\prime \prime}$ & 153 \\
\hline Zone 3 & Lot 4 & Cañete & Quilmaná & Agroberries & $12^{\circ} 58^{\prime} 08^{\prime \prime}$ & $76^{\circ} 21^{\prime} 54^{\prime \prime}$ & 138 \\
\hline Zone 4 & Lot 5 & Cañete & Imperial & Peruvian Prime (Huacachivato) & $13^{\circ} 03^{\prime} 59^{\prime \prime}$ & $76^{\circ} 20^{\prime} 24^{\prime \prime}$ & 98 \\
\hline Zone 5 & Lot 6 y 7 & Cañete & Nuevo Imperial & Fundo a3f- Caltopia & $13^{\circ} 03^{\prime} 49^{\prime \prime}$ & $76^{\circ} 14^{\prime} 30^{\prime \prime}$ & 333 \\
\hline Zone 6 & Lot 8 & Cañete & Quilmaná & Los Ángeles & $12^{\circ} 57^{\prime} 16^{\prime \prime}$ & $76^{\circ} 21^{\prime} 28^{\prime \prime}$ & 159 \\
\hline Zone 7 & Lot 9 & Cañete & Imperial & Arándanos del Sur Cerro Alegre & $13^{\circ} 02^{\prime} 02^{\prime \prime}$ & $76^{\circ} 21^{\prime} 05^{\prime \prime}$ & 137 \\
\hline Zone 8 & Lot 10 & Cañete & Imperial & Malvinas & $13^{\circ} 02^{\prime} 02^{\prime \prime}$ & $76^{\circ} 21^{\prime} 05^{\prime \prime}$ & 137 \\
\hline Zone 9 & Lot 11 & Cañete & Roma & Agroconta & $13^{\circ} 01^{\prime} 20^{\prime \prime}$ & $76^{\circ} 20^{\prime} 47^{\prime \prime}$ & 162 \\
\hline Zone 10 & Lot 12 & Cañete & Quilmaná & Agroconta - Victoria & $12^{\circ} 59^{\prime} 13^{\prime \prime}$ & $76^{\circ} 24^{\prime} 12^{\prime \prime}$ & 110 \\
\hline Zone 11 & Lot 13 & Pisco & Pisco & Agroinversiones Valle y Pampa & $13^{\circ} 48^{\prime} 19^{\prime \prime}$ & $76^{\circ} 03^{\prime} 19^{\prime \prime}$ & 279 \\
\hline
\end{tabular}

Note. The selection of number of plots for each sampling zone is in accordance with availability of plots in the estates with plantations of $V$. corymbosum var. Biloxy of the same age and crop management system. 


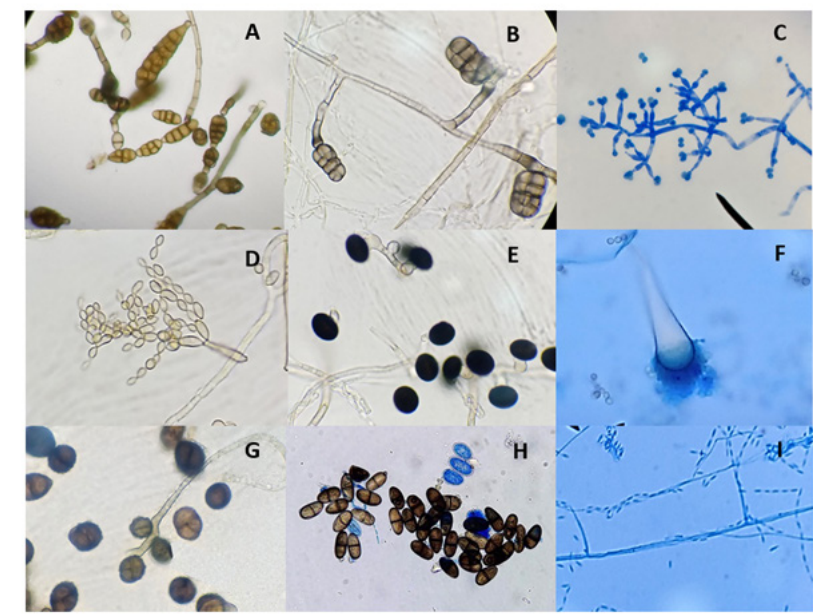

Figure 1. Genera of endophytic fungi identified in Vaccinium corymbosum $L$. from the province of Cañete. Lima Peru. A. Alternaria sp. B. Stemphylium sp. C. Trichoderma sp. D. Cladosporium sp. E. Nigrospora sp. F. Aspergillus sp. G. Ulocladium sp. H. Lasiodiplodia sp. I. Fusarium sp. at 100X.

Genus frequencies of endophytic fungi on leaves and stems of blueberry plants

The genera of the endophytic fungi and the plant organs where they are found vary according to the type of plant organ and the production lot $(\mathrm{p}=0.0054)$ and are associated with the production lots $(\mathrm{p}<0.0001)$.

Of the total strains isolated from blueberry plants, $61.65 \%$ were from leaves and $38.35 \%$ from stems. Being the genera Alternaria, Cladosporium, Fusarium, Nigrospora, Stemphylium and Ulocladium the most frequent in leaves; on the contrary, Aspergillus, Cladosporium, Lasiodiplodia and Trichoderma appeared more frequently in stems. Likewise, of the total strains isolated and identified in stems and leaves, Alternaria and Cladosporiumwere the most frequent genera with $44 \%$ and $23 \%$ respectively, followed by Stemphylium and Nigrospora with 5\%, Trichoderma with $4 \%$ and Fusarium with $3 \%$; while the genera Aspergillus, Lasiodiplodia and Ulocladium were the least frequent with $1 \%$. In the production plots, the relative frequency varied from 3.01 to $14.29 \%$, in plot 2 it was observed with the highest presence of strains of endophytic fungi compared to plot 7 , which was the one with the lowest frequency (figure 2 and table 2).

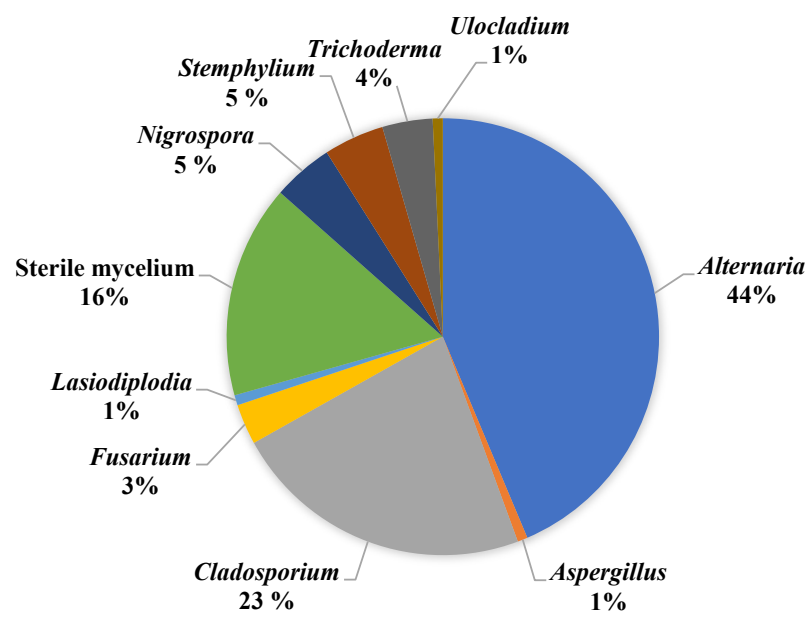

Figure 2. Percentage relative frequency of genera of endophytic fungi isolated from blueberry plants (Vaccinium corymbosum $\mathrm{L}$.) from production plots in the province of Cañete, Peru, 2020.

Table 2. Absolute and relative frequencies with the variables production plots, genera of endophytic fungi, leaves and stems of blueberry plants.

\begin{tabular}{|c|c|c|c|c|c|c|c|c|c|c|c|c|c|c|c|c|c|c|c|c|c|c|}
\hline \multirow{3}{*}{$\begin{array}{l}\text { Production } \\
\text { plots }\end{array}$} & \multicolumn{22}{|c|}{ Genera of endophytic fungi associated with blueberry leaves $(\mathrm{H})$ and stems $(\mathrm{T})$. } \\
\hline & \multicolumn{2}{|c|}{ Alternaria } & \multicolumn{2}{|c|}{ Aspergillus } & \multicolumn{2}{|c|}{ Cladosporium } & \multicolumn{2}{|c|}{ Fusarium } & \multicolumn{2}{|c|}{ Lasiodiplodia } & \multicolumn{2}{|c|}{$\begin{array}{c}\text { Sterile } \\
\text { mycellium }\end{array}$} & \multicolumn{2}{|c|}{ Nigrospora } & \multicolumn{2}{|c|}{ Stemphylium } & \multicolumn{2}{|c|}{ Trichoderma } & \multicolumn{2}{|c|}{ Ulocladium } & \multicolumn{2}{|c|}{ Total } \\
\hline & $\mathbf{H}$ & $\mathbf{T}$ & $\mathbf{H}$ & $\mathbf{T}$ & $\mathbf{H}$ & $\mathbf{T}$ & $\mathbf{H}$ & $\mathbf{T}$ & $\mathbf{H}$ & $\mathbf{T}$ & $\mathbf{H}$ & $\mathbf{T}$ & $\mathbf{H}$ & $\mathbf{T}$ & $\mathbf{H}$ & $\mathbf{T}$ & $\mathbf{H}$ & $\mathbf{T}$ & $\mathbf{H}$ & $\mathbf{T}$ & FA & $\begin{array}{l}\text { FR } \\
(\%)\end{array}$ \\
\hline Plot 1 & 3 & 1 & 0 & 0 & 2 & 0 & 0 & 0 & 0 & 0 & 3 & 0 & 0 & 0 & 2 & 0 & 0 & 0 & 0 & 0 & 11 & 8.27 \\
\hline Plot 2 & 6 & 0 & 0 & 0 & 0 & 4 & 0 & 0 & 0 & 0 & 0 & 0 & 0 & 0 & 0 & 0 & 0 & 0 & 0 & 0 & 10 & 14.29 \\
\hline Plot 3 & 1 & 0 & 0 & 0 & 0 & 0 & 0 & 0 & 0 & 0 & 0 & 0 & 0 & 2 & 0 & 0 & 0 & 1 & 0 & 0 & 4 & 11.28 \\
\hline Plot 4 & 2 & 0 & 0 & 0 & 0 & 2 & 0 & 0 & 0 & 0 & 1 & 0 & 0 & 0 & 0 & 0 & 1 & 0 & 0 & 0 & 6 & 12.03 \\
\hline Plot 5 & 4 & 1 & 0 & 0 & 1 & 0 & 0 & 0 & 0 & 0 & 0 & 1 & 1 & 0 & 0 & 0 & 0 & 0 & 0 & 0 & 8 & 5.26 \\
\hline Plot 6 & 0 & 2 & 0 & 0 & 2 & 1 & 0 & 0 & 0 & 0 & 3 & 0 & 0 & 0 & 0 & 1 & 0 & 0 & 0 & 0 & 9 & 7.52 \\
\hline Plot 7 & 3 & 0 & 0 & 0 & 3 & 1 & 0 & 0 & 0 & 0 & 0 & 0 & 0 & 0 & 0 & 0 & 0 & 0 & 0 & 0 & 7 & 3.01 \\
\hline Plot 8 & 6 & 5 & 0 & 0 & 1 & 0 & 0 & 0 & 0 & 0 & 0 & 1 & 1 & 0 & 0 & 0 & 0 & 0 & 0 & 0 & 14 & 4.51 \\
\hline Plot 9 & 4 & 0 & 0 & 0 & 0 & 3 & 0 & 0 & 0 & 0 & 0 & 0 & 0 & 0 & 0 & 0 & 0 & 0 & 0 & 0 & 7 & 6.02 \\
\hline Plot 10 & 4 & 4 & 0 & 0 & 1 & 2 & 3 & 0 & 0 & 0 & 1 & 0 & 1 & 0 & 2 & 0 & 0 & 0 & 1 & 0 & 19 & 6.77 \\
\hline Plot 11 & 4 & 0 & 0 & 0 & 0 & 1 & 0 & 0 & 0 & 1 & 2 & 3 & 1 & 0 & 1 & 0 & 0 & 2 & 0 & 0 & 15 & 5.26 \\
\hline Plot 12 & 8 & 0 & 0 & 0 & 1 & 2 & 0 & 1 & 0 & 0 & 2 & 2 & 0 & 0 & 0 & 0 & 0 & 0 & 0 & 0 & 16 & 10.53 \\
\hline Plot 13 & 0 & 0 & 0 & 1 & 0 & 3 & 0 & 0 & 0 & 0 & 0 & 2 & 0 & 0 & 0 & 0 & 0 & 1 & 0 & 0 & 7 & 5.26 \\
\hline Total FA & 45 & 13 & 0 & 1 & 11 & 19 & 3 & 1 & 0 & 1 & 12 & 9 & 4 & 2 & 5 & 1 & 1 & 4 & 1 & 0 & 133 & \\
\hline $\begin{array}{c}\text { Total FR } \\
(\%)\end{array}$ & 33.8 & 9.77 & 0 & 0.75 & 8.27 & 14.3 & 2.26 & 0.75 & 0 & 0.75 & 9.02 & 6.77 & 3.01 & 1.5 & 3.76 & 0.75 & 0.75 & 3.01 & 0.75 & 0 & & 100 \\
\hline
\end{tabular}

FA: Absolute frequency RF: Relative frequency expressed as a percentage. 
Of the total isolated strains and genera identified in blueberry plants, Aspergillus and Lasiodiplodia were only found in stems; Similarly, Ulocladium only in leaves compared to the other genera that were isolated in both organs. This is how, in leaves, Alternaria was the most frequent genus with $54.88 \%$ followed by Cladosporium with $13.41 \%$, the opposite resulted in stems, the genus Cladosporium was the most frequent with $37.25 \%$ followed by Alternaria with $25.49 \%$; while the least frequent were Ulocladium and Trichoderma with $1.22 \%$ in leaves, and Aspergillus, Stemphylium and Lasiodiplodia with 1.96\% in stems (figure 3).

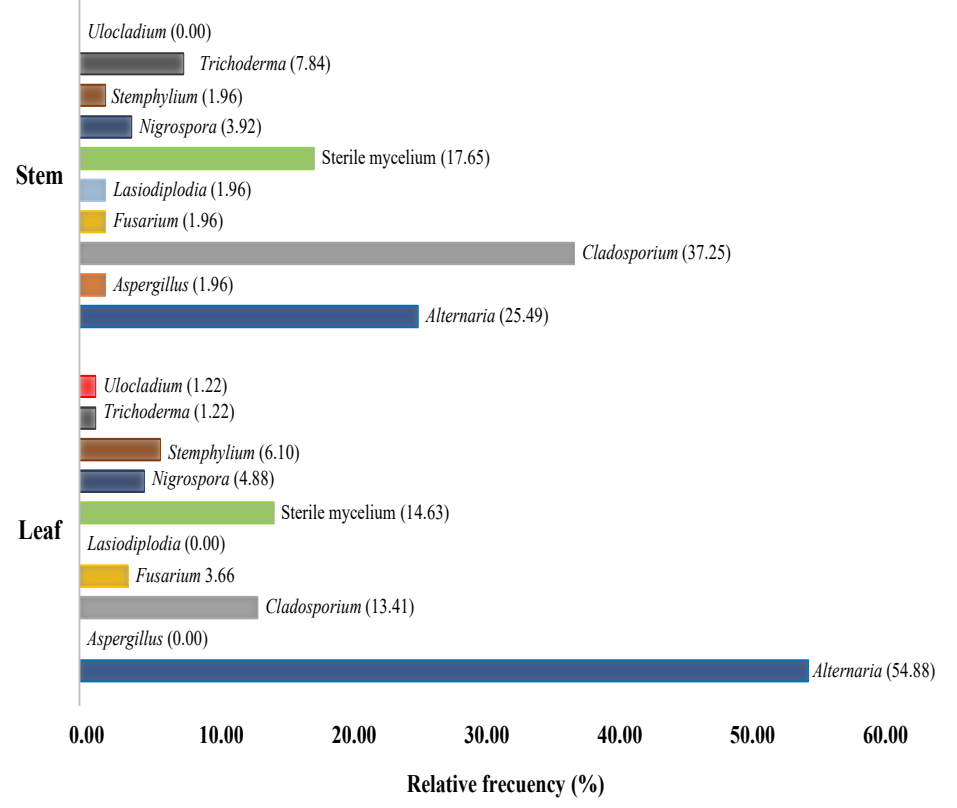

Figure 3. Percentage relative frequency of genera of endophytic fungi at the level of leaves and stems of blueberry plants (Vaccinium corymbosum $\mathrm{L}$.) in the province of Cañete, Peru, 2020.

The colonization of endophytic fungi in the tissues of three-yearold blueberry plants, under a production system in polyethylene bags, varies from $5.56 \%$ to $19.91 \%$, with the Alternaria genus having the highest colonization, followed by Nigrospora; while the genera Aspergillus, Lasiodiplodia and Ulocladium presented the lowest colonization (table 3).

Table 3. Percentage of colonization of genera of endophytic fungi isolated from stems and leaves of blueberry plants in the province of Cañete, Peru, 2020.

\begin{tabular}{lccc}
\hline \multirow{2}{*}{ Genus } & \multicolumn{3}{c}{ Endophytic colonization (\%) } \\
\cline { 2 - 4 } & Leaves & Stems & Plant \\
\hline Alternaria & 10.88 & 9.03 & 19.91 \\
Aspergillus & 0 & 5.56 & 5.56 \\
Cladosporium & 6.12 & 7.04 & 13.16 \\
Fusarium & 8.34 & 5.56 & 13.9 \\
Lasiodiplodia & 0 & 5.56 & 5.56 \\
Sterile mycelium & 6.02 & 6.26 & 12.28 \\
Nigrospora & 5.56 & 11.11 & 16.67 \\
Stemphylium & 6.95 & 5.56 & 12.51 \\
Trichoderma & 5.56 & 7.41 & 12.97 \\
Ulocladium & 5.56 & 0 & 5.56 \\
\hline
\end{tabular}

Of the identified genera, Alternaria and Cladosporium were the most frequent endophytic fungi followed by sterile mycelium (microorganisms did not form reproductive structures); likewise, the greatest diversity was in blueberry leaves. Similar studies indicate that these genera were also the most frequent endophytes in soybeans (Impullitti and Malvick, 2013). On the other hand, Larrain et al. (2000) reported that the highest number of endophytic fungal taxa isolated were from the leaves of healthy wheat plants. Likewise, Cladosporium was one of the genera most frequently isolated from Glycine max leaves (Fernandes et al., 2015). Instead, Cladosporium cladosporioides was sporadically reported on healthy leaves of Caesalpinia echinata Lam. (Lima and Cavalcanti, 2014). They were also reported on the leaves of Vaccinium dunalianum var. Urophyllum the greatest diversity of endophytic fungi and the genus Cladosporium was found in branches (Li et al., 2016). In contrast, a higher number of endophytes were isolated from stem tissues than from leaves in soybean and corn varieties (Russo et al., 2016).

Species of Fusarium, Aspergillus, Alternaria and Nigrospora were reported as stem and leaf endophytes in medicinal plants with a colonization frequency of less than 6.66\% (Anitha et al., 2013). Likewise, the endophytic genera Cladosporium, Nigrospora and Trichoderma were isolated from leaves of Caesalpinia echinata Lam. less frequently (Lima and Cavalcanti, 2014). Similarly, in this investigation, these genera appeared less frequently in the tissues of blueberry plants, as well as Ulocladium, Lasiodiplodia and Stemphilium, except for Alternaria and Cladosporium, which were the ones that presented the highest frequency. On the contrary, Piontelli et al. (2002) reported the genus Ulocladium as the most dominant endophyte in all steps and plant substrates. Likewise, the most frequently isolated species in soybean was Fusarium graminearum and Aspergillus terreus in corn (Russo et al., 2016). Likewise, Ulocladium, Fusarium and Aspergillus sp. were identified as endophytes of palm hearts (Euterpe precatoriaMart.) (Batista et al., 2018). On the other hand, Aharwal and Kumar (2016) reported Aspergillus, Alternaria and Fusarium among the isolated genera of Ricinus communis. Also, the Nigrospora genus was isolated from leaves of healthy Vinca rosea plants (Metwaly et al., 2014). Regarding the genus Lasiodiplodia, there are reports indicating that it is an endophytic fungus of Caesalpinia echinata Lam. (Lima and Cavalcanti, 2014); Similarly, strains of Lasiodiplodia theobromae and Nigrospora sphaerica were identified as endophytes of Theobroma cacao (Vásquez et al., 2018). Therefore, it would be confirmed that the genera identified in this research are endophytic fungi.

These microorganisms colonize inter and/or intracellularly the plant tissue asymptomatically; however, very little is known about the diversity and function of these fungi in species of economic importance (Russo et al., 2016). Thus, Rothen (2015) showed that not all endophytic fungi isolated from G. $\max$ behave in this way, only $26 \%$ behave as endophytes in the strict sense, that is, they do not cause symptoms, and the rest as endophytes in broad sense (17\%), biotrophic pathogens (40\%) and necrotrophic pathogens (17\%) that present symptoms. Therefore, future research is required for the molecular identification at the species level of the isolated strains of $V$. corymbosum and confirm their endophytic capacity. Thus, it would allow the selection of endophytic and pathogenic strains, since there are species of the genera isolated in this study that behave as pathogens of plant species, except for the genus 
Trichoderma, which is used as a biocontrol agent against many phytopathogenic fungi. (Citrus, 2005). In addition, in V. corymbosum, species of Lasiodiplodia (Rodríguez-Gálvez et al., 2020), Nigrospora sphaerica (Wright et al., 2007), Alternaria alternata (Nadziakiewicz et al., 2018), Cladosporium tenuiussimum were identified as pathogens. (Lei et al., 2019), Stemphylium sp. (Flores and Medina, 2012) and Fusarium oxysporum (Moya-Elizondo et al., 2019) with the exception of the Aspergillus, Ulocladium and Trichoderma genera that do not cause disease in blueberry plants. On the contrary, these genera have antifungal activity against phytopathogens (XiaoXue et al., 2018). There are reports indicating that strains of the same species have a great diversity of responses to their host. Thus, some pathogens, before showing disease symptoms, are in a latent phase within the host tissue (Photita et al, 2004), such is the case of $L$. theobromae that behaves as a latent pathogen (Mohali et al., 2005) and as an endophytic antagonist (Vásquez et al., 2018); likewise, certain endophytes can become pathogens when the host plant is stressed, due to excessive humidity or nutrient deficiency, which induce the transition from one way of life to another (Fisher and Petrini, 1992).

In addition, in this research it was found that endophytic fungi colonized less than $20 \%$ of blueberry plant tissues, because the plants are grown in non-sterile conditions, which means that there is competition for other microorganisms (De Souza et al. ,2008). Likewise, the presence of species of endophytic fungi in plants can be affected by many factors, such as the type of culture, type of tissue sampled, age of the plants, climate and location in which they were grown (Impullitti and Malvick, 2013; Russo et al., 2016).

The species of the genus Trichoderma are a group of microorganisms most investigated for the control of fungal plant diseases, they colonize the root surface or live as endophytes within the tissues and have the ability to reduce diseases through their mechanisms of action (mycoparasitism, antibiosis, competition and induced systemic resistance), promote plant growth and improve plant productivity (Bailey and Melnick, 2013). Similarly, Aspergillus versicolor, an endophyte of Vaccinium dunalianum, has inhibitory effects on phytopathogenic fungi (XiaoXue et al., 2018) and has insecticidal activity (Senthilkumar et al., 2014). Also, Alternaria species as a potential biocontrol agent for plant pathogens (Lou et al., 2013) and against some agricultural pests (Sharma and Sharma, 2014). On the other hand, Cladosporium omanense has recently been described as a new endophytic fungus that has the ability to suppress Pythium aphanidermatum (Halo et al., 2021). Therefore, the isolated strains of $V$. corymbosum in the Cañete valley could be possible biological control agents for pests and diseases of blueberries and other crops.

\section{Conclusions}

For the first time, nine genera of endophytic fungi (Trichoderma, Aspergillus, Alternaria, Ulocladium, Cladosporium, Fusarium, Nigrospora, Lasiodiplodia and Stemphylium) and a group of fungi called sterile mycelium were isolated and identified by taxonomic classification in leaves and stems of healthy plants of blueberry variety biloxi from the Cañete valley in Lima, Peru, the leaves being the ones that obtained the highest frequency of strains. The genera Alternaria and Cladosporium turned out to be the most frequent and with the highest colonization in plant tissues, while Aspergillus, Ulocladium and Lasiodiplodia were the least frequent.

\section{Acknowledgment}

Our thanks to Richard Jorge Yactayo Yactayo and José María Espinosa Astorayme for their help with samples collection for the research, and to Yasmin Carmen Arestegui Cantoral and Thalia Esthepany del Pilar Sarmiento Ruiz for their support in isolating fungi.

\section{Funding source}

Financial support from the Universidad Nacional de Cañete- Perú through the Minor Experimental Research Project No. 019 (Contract No. 01-2020-UNDC-PIEM).

\section{Literature cited}

Agrios, G. N. (2005). Plant pathology (5th ed.). Adémica de Elsevier. Burlington. Aharwal, R., \& Kumar, S. (2016). Isolation and Identification of endophytic fungi from Ricinus communis Linn. And their antibacterial activity. International journal of environmental sciences, 6, 1163-1172. https:// doi.org/10.6088/ijes.6111

Anitha, D., Vijaya, T., Pragathi, D., Reddy, N. V., Mouli, K. C., Venkateswarulu, N., \& Bhargav, D. S. (2013). Isolation and characterization of endophytic fungi from endemic medicinal plants of Tirumala Hills. International journal of life sciences biotechnology and pharma research, 2(3), 367373. http://new.ijlbpr.com/jlbpradmin/upload/ijlbpr 51dd838521508.pdf

Arias-Gómez, J., Villasís-Keever, M. Á., y Miranda-Novales, M. G. (2016). El protocolo de investigación III: La población de estudio. Revista alergia México, 63(2), 201 - 206. https://doi.org/10.29262/ram.v63i2.181

Bailey, B. A., \& Melnick, R. L. (2013). The endophytic Trichoderma. En P. K. Mukherjee, B. A. Horwitz, U. S. Singh, M. Mala, \& M. Schmoll (Eds.), Trichoderma: Biology and applications (CABI, pp. 152-172). CABI. https://doi.org/10.1079/9781780642475.0152

Barnett, H. L., \& Hunter, B. B. (1998). Illustrated genera of imperfect fungi. (Third). Macmillan Publishing Company.

Barron, G. L. (1968). The genera of Hyphomycetes from soil. Baltimore. The Williams and Wilkins Co.

Batista, B. N., Raposo, N. V. de M., \& Silva, I. R. da. (2018). Isolamento e avaliação da atividade antimicrobiana de fungos endofíticos de açaizeiro. Revista fitos, 12(2), 161-174. https://doi.org/10.5935/2446-4775.20180015

Busby, P., Ridout, M., \& Newcombe, G. (2016). Fungal endophytes: Modifiers of plant disease. Plant molecular biology review, 90, 645-655. https://doi. org/DOI 10.1007/s11103-015-0412-0

Carroll, G. (1988). Fungal endophytes in stems and leaves: From latent pathogen to mutualistic symbiont. Ecology, 69(1), 2-9. https://doi. org/10.2307/1943154

De Sousa Leite, T., Cnossen-Fassoni, A., Pereira, O., Mizubuti, E., Araújo, E., \& Queiroz, M. (2013). Novel and highly diverse fungal endophytes in soybean revealed by the consortium of two different techniques. Journal of microbiology., 5l(1), 56-69. https://doi.org/10.1007/s12275-0132356-X

Di Rienzo, J. A., Casanoves, F., Balzarini, M. G., Gonzalez, L., Tablada, M., y Robledo, C. W. (2008). InfoStat software estadístico, Manual del Usuario: Vol. Grupo Infostad (1.1) [Computer software]. Universidad Nacional de Córdoba.

Fan, M., Chen, X., Luo, X., Zhang, H., Liu, Y., Zhang, Y., Wu, J., Zhao, C., $\&$ Zhao, P. (2020). Diversity of endophytic fungi from the leaves of Vaccinium dunalianum. Letters in applied microbiology, 71(5), 479-489. https://doi.org/10.1111/lam.13345

Fernandes, E. G., Pereira, O. L., Silva, C. C. da, Bento, C. B. P., \& Queiroz, M. V. (2015). Diversity of endophytic fungi in Glycine max. Microbiological research, 181, 84-92. https://doi.org/10.1016/j.micres.2015.05.010

Fisher, P. J., \& Petrini, O. (1992). Fungal saprobes and pathogens as endophytes of rice (Oryza sativa L.). New phytologist, 120(1), 137-143. https://doi. org/10.1111/j.1469-8137.1992.tb01066.x

Flores, A. M., y Medina, J. L. (2012). Hongos asociados a la parte aérea del arándano en Los Reyes, Michoacán, México. Revista mexicana de fitopatología, 30(2), 141-144. http://www.scielo.org.mx/pdf/rmfi/v30n2/ v30n2a4.pdf

Halo, B. A., Al-Yahyai, R. A., \& Al-Sadi, A. M. (2021). Biological control of Pythium aphanidermatum-induced cucumber and radish damping-off by an endophytic fungus, Cladosporium omanense isolate 31R. Biocontrol science and technology, 31(3), 235-251. https://doi.org/10.1080/095831 57.2020 .1844148

Impullitti, A. E., \& Malvick, D. K. (2013). Fungal endophyte diversity in soybean. Journal of Applied microbiology, 114(5), 1500-1506.

Larran, S., Mónaco, C., \& Alippi, H. E. (2000). Endophytic fungi in beet (Beta vulgaris var. Esculenta L.) leaves. Advances in horticultural science, 14(4), 193-196. https://www.jstor.org/stable/42883275 
Lei, Y., JianRong, W., Jia, D., YanYuan, L., \& Fang, W. (2019). Pathogen identification of rotten blueberry fruit in post-harvest and screening of antagonistic bacteria. Journal of fujian agriculture and forestry university (Natural science edition), 48(2), 143-147. https://www.cabdirect.org/ cabdirect/abstract/20219924337

Li, Z.-J., Shen, X.-Y., \& Hou, C.-L. (2016). Fungal endophytes of South China blueberry (Vaccinium dunalianum var. Urophyllum). Letters in applied microbiology, 63(6), 482-487. https://doi.org/10.1111/lam.12673

Lima, T. E. F., \& Cavalcanti, M. S. (2014). Fungos endófitos e do filoplano de Caesalpinia echinata lam da estação ecológica de Tapacurá, PE. Agrotrópica, 26(1), 43-50.

Lou, J., Fu, L., Peng, Y., \& Zhou, L. (2013). Metabolites from alternaria fungi and Their bioactivities. Molecules, 18(5), 5891-5935. https://doi.org/10.3390/ molecules 18055891

Lugtenberg, B. J. J., Caradus, J. R., \& Johnson, L. J. (2016). Fungal endophytes for sustainable crop production. FEMS Microbiology ecology, 92(12). https://doi.org/10.1093/femsec/fiw194

Mane, R. S., Paarakh, P. M., \& Vedamurthy, A. B. (2018). Brief review on fungal endophytes. International journal of secondary metabolite, 5(4), 288303. https://doi.org/10.21448/ijsm.482798

Metwaly, A. M., Kadry, H. A., Atef, A., Mohammad, A.-E. I., Ma, G., Cutler, S. J., $\&$ Ross, S. A. (2014). Nigrosphaerin a new isochromene derivative from the endophytic fungus Nigrospora sphaerica. Phytochemistry letters, 7 , $1-5$.

Miao, Y., Wang, H., Li, G., Zhang, Z., y Tang, L. (2013). Morfología y estructura de las micorrizas y distribución de hongos endofíticos en Vaccinium uliginosum L.en la montaña Changbai. Journal of northeast agricultural university, 44(1), 81-85. https://en.cnki.com.cn/Article_en/CJFDTotalDBDN201301017.htm

Mohali, S., Burgess, T. I., \& Wingfield, M. J. (2005). Diversity and host association of the tropical tree endophyte Lasiodiplodia theobromae revealed using simple sequence repeat markers. Forest pathology, 35, 385-396. https:// doi.org/10.1111/j.1439-0329.2005.00418.x

Moya-Elizondo, E. A., Doussoulin, H., San Martin, J., Ruiz, B., \& Del Valle, P. (2019). First report of Fusarium oxysporum causing Fusarium wilt on blueberry (Vaccinium corymbosum) in Chile. Plant disease, 103(10), 2669-2669. https://doi.org/10.1094/PDIS-02-19-0275-PDN

Nadziakiewicz, M., Kurzawińska, H., Mazur, S., \& Tekielska, D. (2018). Alternaria alternata - the main causal agent of disease symptoms in juniper, rose, yew and highbush blueberry in nurseries in Southern Poland. Folia horticulturae, 30(1), 15-25. https://doi.org/10.2478/fhort-2018-0002

Photita, W., Lumyong, S., Lumyong, P., C, E. H., \& Hyde, K. D. (2004). Are some endophytes of Musa acuminata latent pathogens? Fungal diversity, 16, 131-140. https://citeseerx.ist.psu.edu/viewdoc/ download?doi=10.1.1.563.2343\&rep=rep1\&type=pdf

Piontelli. L, E., Toro S.M., M. A., Giusiano, G., $y$ Vivar, V. (2002). Distribución altitudinal de hongos queratinofilos, epifitos y endófitos en suelos desérticos del norte chileno (II Región, $23^{\circ} \mathrm{L} . \mathrm{S}$ Y $68^{\circ} \mathrm{L}$.W). Boletín micológico, 17(1), 33-49. https://doi.org/10.22370/bolmicol.2002.17.0.436
Redagricola. (01 de abril del 2020). El arándano peruano alcanza el liderazgo mundial. Redagrícola Perú. https://www.redagricola.com/pe/arandanoperuano-alcanza-liderazgo-mundial/

Rodríguez-Gálvez, E., Hilário, S., Lopes, A., \& Alves, A. (2020). Diversity and pathogenicity of Lasiodiplodia and Neopestalotiopsis species associated with stem blight and dieback of blueberry plants in Perú. European journal of plant pathology, 157(1), 89-102. https://doi.org/10.1007/ s10658-020-01983-1

Rothen, C. P. (2015). Hongos endofitos septados en raices de Glycine max: Diversidad, caracterización y estudio de la interacción [Doctoral, Universidad de Buenos Aires]. https://bibliotecadigital.exactas.uba.ar/ download/tesis/tesis_n5794_Rothen.pdf

Russo, M. L., Pelizza, S. A., Cabello, M. N., Stenglein, S. A., Vianna, M. F., \& Scorsetti, A. C. (2016). Endophytic fungi from selected varieties of soybean (Glycine max L. Merr.) and corn (Zea mays L.) grown in an agricultural area of Argentina. Revista Argentina de microbiología, 48(2), 154-160. https://doi.org/10.1016/j.ram.2015.11.006

Segaran, G., \& Sathiavelu, M. (2019). Fungal endophytes: A potent biocontrol agent and a bioactive metabolites reservoir. Biocatalysis and agricultural biotechnology, 21, 101284. https://doi.org/10.1016/j.bcab.2019.101284

Senthilkumar, N., Murugesan, S., \& Babu, D. S. (2014). Metabolite profiling of the extracts of endophytic fungi of entomopathogenic significance, Aspergillus flavus and Nigrospora sphaericaisolated from tropical tree species of India, Tectona grandis L. Journal of agriculture and life Sciences, $1(1), 108-114$. http://jalsnet.com/journal/index/2133

Sharma, I., \& Sharma, A. (2014). Use of Alternaria spp.as a pest control agent: A review. World applied sciences journa,11(31),1869-1872. https://doi. org/10.5829/idosi.wasj.2014.31.11.83163

Vásquez, M. V., Lozano, R. E., Martínez, S. P., y Castillo, D. S. del. (2018). Hongos endófitos foliares como candidatos a biocontroladores contra Moniliophthora spp. De Theobroma cacao (Malvaceae) en Ecuador. Acta Biológica Colombiana, 23(3), 235-241. https://doi.org/10.15446/abc. v23n3.69455

Watanabe, T. (2002). Pictorial atlas of soil and seed fungi. Morphologies of cultured fungi and key to species. (Second). CRC PRESS.

Wright, E. R., Folgado, M., Rivera, M. C., Crelier, A., Vasquez, P., \& Lopez, S. E. (2007). Nigrospora sphaerica causing leaf spot and twig and shoot blight on blueberry: A new hos of the pathogen. Plant disease, 92(1), 171-171. https://doi.org/10.1094/PDIS-92-1-0171B

XiaoXue, C., MiaoMiao, F., He, Z., XuLu, L., ChangLin, Z., JianRong, W., Jing, L., \& Ping, Z. (2018). Identification and antifungal activity of an endophytic fungus from Vaccinium dunalianum. Journal of southwest forestry university, 38(4), 187-192. https://www.cabdirect.org/cabdirect/ abstract/20193063255 